\title{
Community structure and tree diversity in a subtropical forest in southern Brazil
}

\author{
Kauane Maiara Bordin ${ }^{1 *}$, Letícia Daiana Ferreira ${ }^{2}$, Adriano Rosina ${ }^{2}$, Marciana Malacarne ${ }^{2}$, Patricia \\ Zanotelli $^{2}$, Samuel Fernando Adami ${ }^{3}$ \& Giovana Secretti Vendruscolo ${ }^{3}$ \\ ${ }^{1}$ Universidade Federal do Rio Grande do Sul, Laboratório de Ecologia Vegetal, Programa de Pós-Graduação \\ em Ecologia, Porto Alegre, RS, Brasil \\ ${ }^{2}$ Universidade Comunitária da Região de Chapecó, Chapecó, SC, Brasil \\ ${ }^{3}$ Universidade Federal da Integração Latino-Americana, Programa de Pós-Graduação em Biodiversidade \\ Neotropical, Foz do Iguaçu, PR, Brasil \\ *Corresponding author: Kauane Maiara Bordin, e-mail: kauanembordin@gmail.com
}

BORDIN, K.M., FERREIRA, L.D., ROSINA, A., MALACARNE, M., ZANOTELli, P., ADAMI, S.F., VENDRUSCOLO, G.S. Community structure and tree diversity in a subtropical forest in southern Brazil. Biota Neotropica. 19(2): e20180606. http://dx.doi.org/10.1590/1676-0611-BN-2018-0606

\begin{abstract}
Local and regional environmental variations lead to different species composition, creating transitional areas. An example is the Araucaria and Seasonal forest in southern Brazil. Our objectives were (1) to describe the tree community structure and composition of a subtropical forest in southern Brazil and (2) to compare the floristic relationships between two forest typologies (Araucaria and Seasonal forest) in order to characterize the study area and the distribution patterns of tree species. We conducted a survey at Chapecó National Forest (in southern Brazil) in an area of $1.2 \mathrm{ha}$, where all individuals $\geq 30 \mathrm{~cm}$ of circumference at breast height were sampled. Community structure was described using the traditional phytosociological parameters. The floristic relationships were obtained by comparing our results with compiled data from other scientific papers through cluster analyses using an unweighted average linkage method, based on Jaccard similarity coefficient. We sampled 809 individuals belonging to 61 species and 28 families. The richest family was Fabaceae and Coussarea contracta (Walp.) Müll.Arg. was the most abundant species. Taxonomic diversity was 3.06 and the evenness was 0.74 . The floristic similarity revealed that species composition of our study area is more similar to Seasonal forest. Species composition is related to environmental factors such as great thermal amplitude and seasonality. This subtropical forest is well structured, highly diverse and extremely important for the local and regional biodiversity conservation.

Keywords: Araucaria forest, Biodiversity conservation, Floristic similarity, Phytosociology, Seasonal forest, Transitional forest.

\section{Estrutura da comunidade e diversidade de espécies arbóreas em uma floresta subtropical no sul do Brasil}

Resumo: Variações ambientais locais e regionais levam à composição de espécies diferentes e áreas de transições. Um exemplo é a floresta com araucária e a floresta estacional no sul do Brasil. Nossos objetivos foram (1) descrever a composição e estrutura da comunidade arbórea de uma floresta subtropical no sul do Brasil e (2) comparar as relações florísticas entre duas tipologias florestais (Floresta com Araucária e Floresta Estacional) a fim de caracterizar a área de estudo e o padrão de distribuição de espécies arbóreas. Nós realizamos uma pesquisa na Floresta Nacional de Chapecó (no sul do Brasil) em uma área de 1.2 hectares, onde todos os indivíduos com circunferência à altura do peito $\geq 30 \mathrm{~cm}$ foram amostrados. A estrutura da comunidade foi descrita utilizando os parâmetros fitossociológicos tradicionais. Obtivemos as relações florísticas através da comparação dos nossos resultados com dados compilados de outros trabalhos científicos, através de análises de agrupamento (método de ligação de distância média não ponderada, UPGMA, baseado no coeficiente de similaridade de Jaccard). Foram amostrados 809 indivíduos pertencentes a 61 espécies e 28 famílias. A família mais rica foi Fabaceae e Coussarea contracta (Walp.) Müll.Arg. a espécie mais abundante. A diversidade taxonômica foi de 3.06 e a equabilidade foi de 0.74. A similaridade florística revelou que a composição de espécies da nossa área de estudo é mais similar a da floresta estacional. A composição de espécies está relacionada a fatores ambientais como a amplitude térmica e sazonalidade. Esta floresta subtropical é bem estruturada, altamente diversa e muito importante para a conservação da biodiversidade local e regional.

Palavras-chave: Floresta com araucária, Conservação da biodiversidade, Similaridade florística, Fitossociologia, Floresta estacional, Floresta de transição. 


\section{Introduction}

The community species composition results from processes that rule the assemblages. In general, the processes are related to neutral models (Hubbell 2001), niche-based models (Cornwell \& Ackerly 2009) or both, in different scales (Xu et al. 2017). In general, the first are related to stochastic variations in the community (eg. dispersal limitations), and the second, to the influence of the environmental filters on species. These environmental filters are related to abiotic factors that prevent the establishment or persistence of a species in a location (eg. temperature, precipitation, and soil conditions) (Kraft et al. 2015, Oliveira-Filho et al. 2001).

The environmental characteristics can vary along the extent of an area, creating some special conditions to the development and occurrence of a set of species. Factors such as soil composition, rainfall patterns, latitudinal and altitudinal ranges lead to floristic differentiations (Liebsch et al. 2008). These variations create gradients (or ecotones), known as transitional areas with great biodiversity, especially because of the overlap of different physiognomies (Risser 1995). In general, studies in these areas are mainly in the transition of forested and non-forested areas (Junyan et al. 2014), and the forest-forest dynamics is poorly documented, especially because of the gaps in knowledge about the capacity of rearrangement of species distribution (Oliveira-Filho et al. 2014).

The Brazilian Atlantic Forest is one of the biodiversity hotspots of the world, because of the great endemism of species in this area (Myers et al. 2000). Originally, it covered more than $1,400.000 \mathrm{~km}^{2}$ of Brazilian territory (Joly et al. 2014) and the geographical location ranges from the northeastern to southern Brazil (Morellato \& Haddad 2000, Joly et al. 2014). The Atlantic Forest is defined by Oliveira-Filho and Fontes (2000) as sensu stricto (s.s.) and sensu lato (s.l.). The first is related to the forests along the Atlantic Ocean and the second, as a biome, to a set of physiognomies present at the extent of its distribution. In this study, we considered the concept of Atlantic Forest s.l., including the forest physiognomies (Oliveira-Filho \& Fontes 2000).

The floristic differences can be generated by local environmental factors, such as river valleys (important corridors of arboreal species dispersal) (Spichiger et al. 2004), edaphic factors, local topography and disturbances (Higuchi et al. 2012, Gonçalves \& Souza 2014, Estevan et al. 2016). In the southern Brazil region, heterogeneous climatic conditions allow the occurrence of many different groups of species (Higuchi et al. 2012). In general, they are a mixture of tropical elements from Amazon region and temperate Austral-Antartic and Andean floras (Rambo 1951).

As a consequence of this heterogeneity, many transitional areas are found in this region. For example, the Araucaria forest is surrounded by the Atlantic forest s.s. (i.e. Dense ombrophilous forest), Seasonal forest, grasslands and other vegetation types (Klein 1978; Overbeck et al. 2007; IBGE 2012). However, little is known about the floristic patterns of the arboreal components of these forests (Higuchi et al. 2012), especially in transitional areas. In order to answer these questions, we had two objectives in this study. In the first, we aimed at describing the tree community structure and composition of a subtropical forest in southern Brazil. In the second, we aimed at comparing the floristic relationships between two forest typologies (Araucaria and Seasonal forests) in order to characterize the study area and to contribute to the knowledge on the distribution patterns of tree species.

\section{Material and Methods}

\section{The southern Brazilian Atlantic Forest: the Araucaria and Seasonal forests}

The forest typologies in Santa Catarina state were initially described in an extensive fieldwork by the botanists Raulino Reitz and Roberto Miguel Klein (Klein 1978, 1960, Reitz et al. 1978, Klein 1963). Their results were summarized in two publications - the "Flora Ilustrada Catarinense" (in many papers since 1965) and the "Projeto Madeira de Santa Catarina" (Reitz et al. 1978), who became important for the knowledge about Santa Catarina's flora. Recently, another project was conducted in the state ("The Floristic and Forest Inventory of Santa Catarina State" (Vibrans et al. 2010)) and resulted in many papers and books about the species occurrence, plant genetic information and economic aspects of the population surrounding the forest (Vibrans et al. 2013a, b, 2010).

The results obtained from the inventory for Araucaria forest (AF) and Seasonal forest (SF) were summarized by Gasper, Uhlmann, et al. (2013) and Gasper, Sevegnani, et al. (2013) where they recorded 366 and 204 tree species, respectively. In the southern Atlantic forest s.l., the presence of the conifer Araucaria angustifolia (Bertol.) Kuntze characterizes the AF. This species occurs at the Santa Catarina's plateau in elevations between $500 \mathrm{~m}$ to $1,500 \mathrm{~m}$ above sea level (a.s.l.) (Backes 2009). The climatic conditions for its occurrence are low temperature $\left(12{ }^{\circ} \mathrm{C}\right.$ in average) and high humidity $(1.830 \mathrm{~mm}$ in average) (Rambo 1953, Backes 2009). Other species frequently associated with this forest are Nectandra lanceolata Nees, Eugenia involucrata DC., Ocotea diospyrifolia (Meisn.) Mez, Ilex paraguariensis A.St.-Hil. and Cupania vernalis Cambess. (Klein 1978; Jarenkow and Budke 2009). Otherwise, the Seasonal forest, also known as "Upper Uruguay River Basin" forest, is characterized by deciduous species (who lose their leaves in the cold season). It occurs in elevations between $150 \mathrm{~m}$ to $800 \mathrm{~m}$ a.s.l (Klein 1978, Gasper, Uhlmann, et al. 2013) and the temperature in the region is lower than $15^{\circ} \mathrm{C}$ in average. Other species associated with this forest are Apuleia leiocarpa (Vogel) J.F.Macbr., Diatenopteryx sorbifolia Radlk., Peltophorum dubium (Spreng.) Taub. and Myrocarpus frondosus Allemão (Gasper, Uhlmann, et al. 2013, Klein 1978).

The west of the Santa Catarina state was traditionally characterized as a transitional area, composed by Araucaria and Seasonal forests. According to IBGE (2012), this region is substantially covered by Seasonal forest; However, Klein (1960) described it as Araucaria forest, mainly. Furthermore, many authors agree that the dynamics of these forests follow a west-east pattern and the species that compose the SF advances over the AF (Backes 2009; Waechter 2009; Jarenkow and Budke 2009; Gasper et al. 2013b, 2015).

\section{Study area}

The sampling was conducted at Chapecó National Forest (glebe one), a Conservation Unit for sustainable use located in the west of

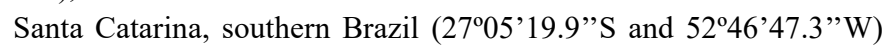
(Figure 1) (see details in Lucas \& Fortes 2008). The climate is subtropical (Nimer 1989); the annual rainfall is well distributed during the year (the average rainfall is $2000 \mathrm{~mm}$ ) and the average temperature ranges from $22^{\circ} \mathrm{C}$ to $14{ }^{\circ} \mathrm{C}$ for the hotter and coldest month, respectively (http://www.inmet.gov.br). The regional landforms are characterized by the hilly topography of the Araucarias' Plateau, between $520 \mathrm{~m}$ 


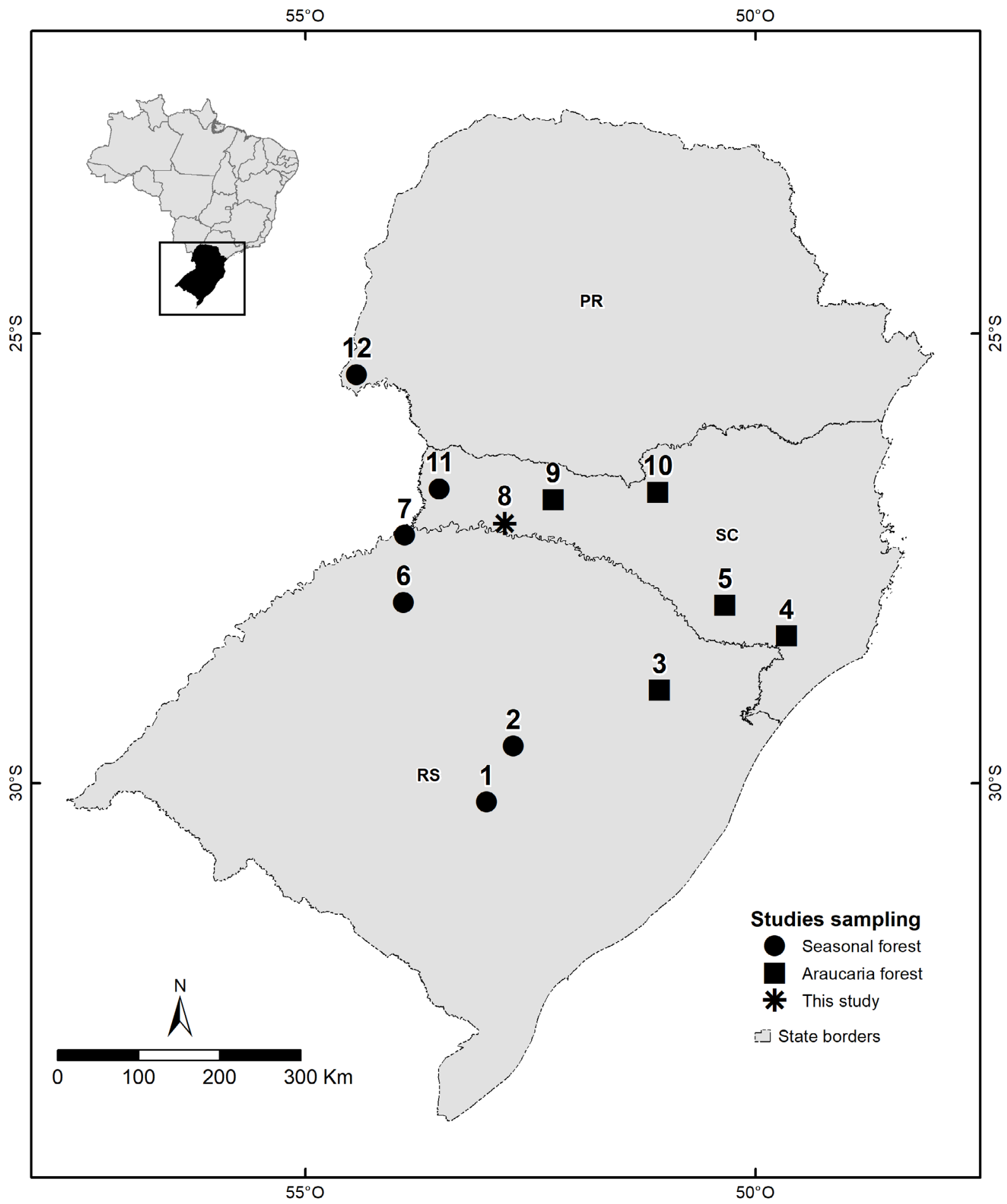

Figure 1. Location of the study area, at Chapecó National Forest, west Santa Catarina, southern Brazil (code number $8-*$ ). Information about Araucaria forest is presented as quadrats (numbers 9-12) and Seasonal forest as circles (numbers 1-7). Complete information about data sources data can be accessed in Table 1.

and $617 \mathrm{~m}$ a.s.l. and the predominant soils are Inceptisols and Oxisols (ICMBio 2013).

\section{Sampling units and data analysis}

The survey was conducted in a secondary forest, with more than 60 years without disturbance (in 2017). There, 24 permanent plots were systematically selected with $500 \mathrm{~m}^{2}$ each one $(50 \mathrm{~m} \mathrm{x} 10 \mathrm{~m})$, corresponding to a total area of 1.2 ha. To describe the community structure we measured trees $\geq 30 \mathrm{~cm}$ of circumference at breast height (c.b.h.) (which means $\geq 9.54 \mathrm{~cm}$ of diameter at breast height, d.b.h.). The maximum height was estimated for all individuals. Whenever possible, the individuals had species determination in field. For those which determination was not possible, we collected material for determination in laboratory. Voucher specimens were deposited in the 
UNO Herbarium (UNO, at Universidade Comunitária da Região de Chapecó). The circumscription adopted for angiosperm families are in accordance with Angiosperm Phylogeny Group (The Angiosperm Phylogeny Group 2016).

The community structure was described using the phytosociological parameters (Mueller-Dombois \& Ellenberg 1974). We evaluated the sample adequacy using a rarefaction curve (Magurran 2004) with the software Estimates 8.2, considering $\alpha \leq 0.05$. Taxonomic diversity was estimated using the Shannon-Weiner Index (H') and Pielou's evenness Index (J) ( $R$ version 3.3.1, vegan package) ( $R$ Core Team 2016).

To evaluate the floristic similarity we compiled information from scientific papers. Our selection criterion followed the conditions: a) survey at Araucaria or Seasonal forests and b) range of study restricted to southern Brazil, with the maximum distance of $350 \mathrm{~km}$ from the Chapecó National Forest (our study area) and more than $50 \mathrm{~km}$ between the surveys (data sources) to remove a possible effect of proximity, also considering, as possible, studies with similar sampling method and data collection effort (Fig. 1). We selected 12 papers, and most part of surveys employed plots for vegetation sampling; once a study used point-centered quarters (Benvenuti-Ferreira \& Coelho 2009). The studies differ in regard to sampling effort and size criteria for individual inclusion (minimum c.b.h.). The information about each study is described in Table 1. We integrated our results to the matrix of compiled data and used an abundance matrix. The final matrix was composed by 145 arboreal species (genus and families identifications were excluded). We performed cluster analyses using an unweighted average linkage method (UPGMA) based on a Jaccard similarity coefficient (Legendre \& Legendre 2012) (R version 3.3.1, vegan package).

\section{Results}

We sampled 809 individuals belonging to 61 species and 28 families. Families with the largest number of species were: Fabaceae (11), Lauraceae (5), Rutaceae (5), Salicaceae (4) and Sapindaceae (4) (Table 2). The mean density was 674 individuals/ha. Coussarea contracta (Walp.) Müll.Arg., Ocotea diospyrifolia (Meisn.) Mez, Cupania vernalis Cambess., Araucaria angustifolia, Casearia sylvestris Sw., Diatenopteryx sorbifolia Radlk. and Myrocarpus frondosus Allemão were the species with biggest relative density, representing $62.7 \%$ of the individuals sampled. These species even had the biggest relative dominance in basal area (more than 54\%), relative frequency $(37.9 \%)$, coverage value $(58.2 \%)$ and importance value $(51.5 \%)$ (Table 2$)$. According to the Shannon index, the taxonomic diversity was 3.06 and the evenness $(\mathrm{J})$ was 0.74 (Table 1 ). However, the rarefaction curve did not reach an asymptotic richness level (Figure 2).

The diameter structure followed the traditional inverted-J curve, with most of the individuals at the first diameter class (almost 50\%) (Figure 2). Individuals with largest diameter are represented by Luehea divaricata Mart. \& Zucc. (107 cm d.b.h) and A. angustifolia $(81.5 \mathrm{~cm}$ d.b.h.). Most of the individuals were from six to 15 meters height and, in general, the abundance decreased as the height grew up (Figure 2). The emergent species (over $20 \mathrm{~m}$ height) were $A$. angustifolia, D. sorbifolia, M. frondosus, $O$. diospyrifolia, Helietta apiculata Benth., Lamanonia ternata Vell., Matayba elaeagnoides Radlk., Parapiptadenia rigida (Benth.) Brenan, Peltophorum dubium (Spreng.) Taub. and Prunus myrtifolia (L.) Urb.

Table 1. Data compiled from studies at Araucaria and Seasonal forests in order to evaluate the species similarity. Source: papers where the data were obtained; SL: sampling location; CO: site code; A: total sampled area (in hectares); c.b.h: minimum tree circumference criteria (cm); N: number of species sampled; RF: Richest families at community; Abundant species: Most abundant species at community; Total abundance: number of individuals sampled at community; RD: Araucaria angustifolia relative dominance at community; H': Shannon-Wiener diversity index; J: Pielou's evenness index.

\begin{tabular}{|c|c|c|c|c|c|c|c|c|c|c|c|}
\hline Source & SL & CO & $\mathbf{A}$ & c.b.h. & $\mathbf{N}$ & RF & Abundant species (N) & $\begin{array}{c}\text { Total } \\
\text { abundance }\end{array}$ & $\begin{array}{l}\text { RD } \\
(\%)\end{array}$ & $\mathbf{H}^{\prime}$ & $\mathbf{J}$ \\
\hline This study & $\mathrm{SC}$ & 8 & 1,2 & 30 & 61 & $\begin{array}{l}\text { Fabaceae (11); } \\
\text { Lauraceae (5); } \\
\text { Rutaceae (5); } \\
\text { Salicaceae (4); } \\
\text { Sapindaceae (4) }\end{array}$ & $\begin{array}{l}\text { Coussarea contracta }(177) ; \\
\text { Ocotea diospyrifolia }(110) ; \\
\text { Cupania vernalis }(84) ; \\
\text { Araucaria angustifolia }(45) ; \\
\text { Casearia sylvestris }(32) .\end{array}$ & 809 & 5,5 & 3,06 & 0,74 \\
\hline \multicolumn{12}{|c|}{ Seasonal forest } \\
\hline $\begin{array}{l}\text { Lindenmaier \& } \\
\text { Budke (2006) }\end{array}$ & RS & 1 & 1 & 15 & 49 & $\begin{array}{l}\text { Myrtaceae (7); } \\
\text { Meliaceae (4); } \\
\text { Salicaceae (5); } \\
\text { Fabaceae }(5)\end{array}$ & $\begin{array}{l}\text { Eugenia ramboi }(397) ; \\
\text { Cordia americana }(111) ; \\
\text { Sorocea bomplandii }(94) ; \\
\text { Casearia sylvestris }(68) ; \\
\text { Cabralea canjerana }(56) \text {. }\end{array}$ & 1097 & - & 2,68 & 0,66 \\
\hline $\begin{array}{l}\text { Jarenkow } \\
\text { \& Waechter } \\
(2001)\end{array}$ & RS & 2 & 1 & 15,7 & 55 & $\begin{array}{l}\text { Fabaceae (7); } \\
\text { Myrtaceae (6); } \\
\text { Euphorbiaceae (5); } \\
\text { Lauraceae (5); } \\
\text { Meliaceae (5) }\end{array}$ & $\begin{array}{l}\text { Gymnanthes concolor (632); } \\
\text { Euterpe edulis }(434) ; \\
\text { Sorocea bomplandii }(255)\end{array}$ & 1855 & - & 2,24 & 0,56 \\
\hline $\begin{array}{l}\text { Benvenuti- } \\
\text { Ferreira \& } \\
\text { Coelho (2009) }\end{array}$ & RS & 6 & 0,25 & 15,7 & 63 & $\begin{array}{l}\text { Fabaceae (11); } \\
\text { Myrtaceae (4); } \\
\text { Rutaceae (4); } \\
\text { Sapindaceae (4); } \\
\text { Lauraceae (4); } \\
\text { Euphorbiaceae (4) }\end{array}$ & $\begin{array}{l}\text { Cordia americana }(45) ; \\
\text { Diatenopteryx sorbifolia }(39) ; \\
\text { Prunus myrtifolia }(27) ; \\
\text { Matayba elaeagnoides }(26) ; \\
\text { Machaerium stipitatum }(22) .\end{array}$ & 508 & - & 3,68 & 0,89 \\
\hline
\end{tabular}


Continuation Table 1.

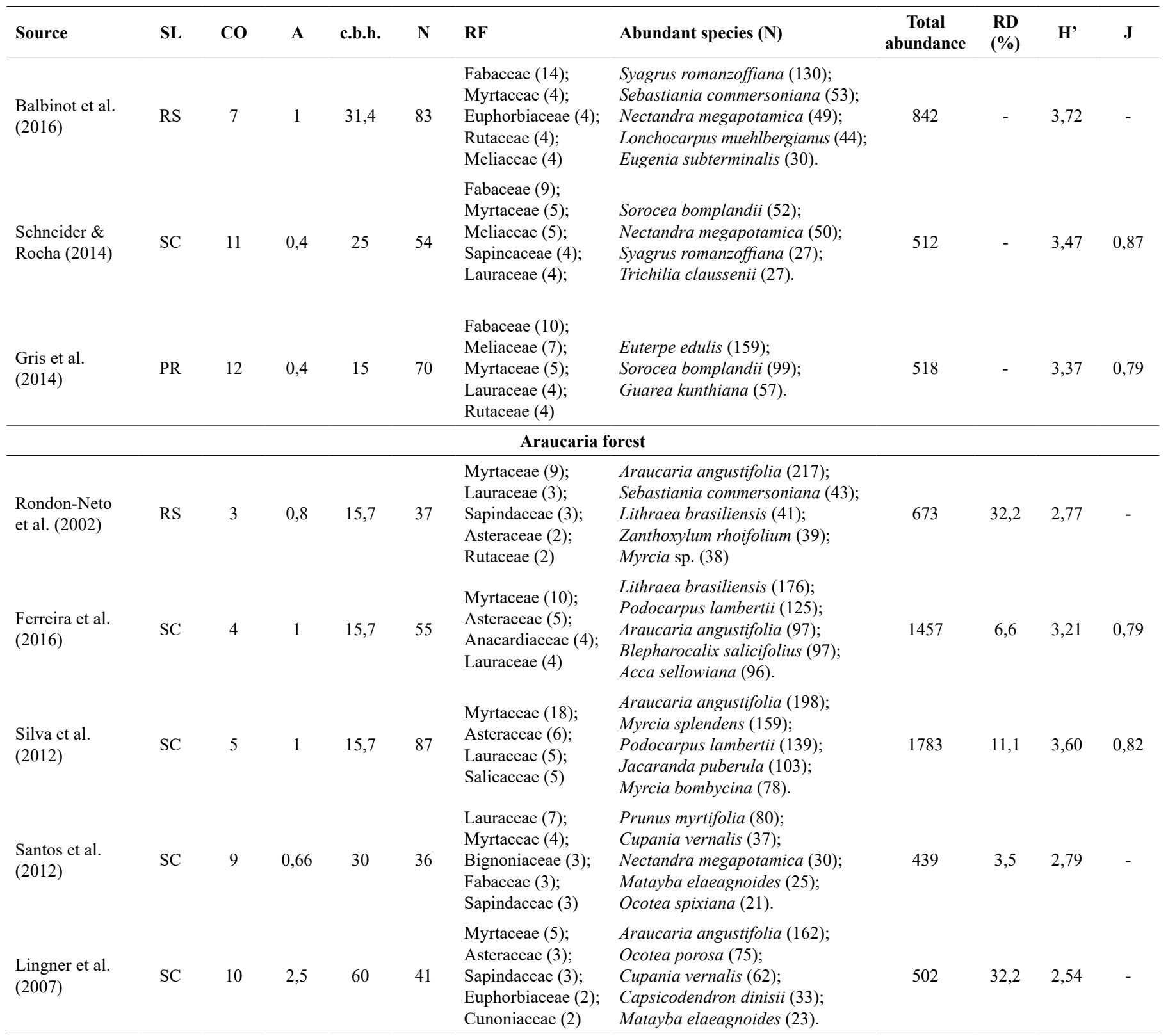

Floristic similarity revealed that our study area (code number $\left.8-^{*}\right)$ was more similar to the species composition of Seasonal forest (cophenetic correlation coefficient: 0.9092) (Figure 3). The cluster indicated two groups, and the first division was between species composition from both two forest typologies. Seasonal forest group was divided according to the hydrography: forests from the upper Uruguay and Paraná and Jacuí river basins. On the other hand, the higher altitude was important for the Araucaria forest in the southern Brazilian mountains. Furthermore, surveys geographically closer were more similar in species composition; Fabaceae has a greater richness in Seasonal forests from Uruguay and Paraná river basins, Myrtaceae is highly represented in Araucaria forests from northeastern Rio Grande do Sul, and Lauraceae is well distributed in both forest typologies (Table 1, Fig.1). In terms of species composition, M. elaeagnoides, P. myrtifolia, Allophylus edulis (A.St.-Hil., Cambess. \& A. Juss.) Radlk, Campomanesia xanthocarpa O.Berg, Cedrela fissilis Vell. and
Nectandra megapotamica (Spreng.) were registered in most part of the studies and also in our sampling. Otherwise, A. angustifolia was sampled only in Araucaria forests, broadly associated to higher altitudes in Santa Catarina and Rio Grande do Sul states.

\section{Discussion}

\section{Tree community structure and composition in a subtropical forest in southern Brazil}

The tree taxonomic diversity and evenness indexes found in this study had intermediate values when compared to other surveys in southern Brazil (Table 1). These indexes indicated the balance of few dominant species and many species with lower abundance. This result reflects the ecological stability and maturity of the community (Wright 2007, Warring et al. 2016). 
Table 2. Structural parameters of the tree community surveyed at Chapecó National Forest, west Santa Catarina, southern Brazil. Species: identification of the species sampled in this study; N: number of individuals; RD: relative density (\%); RF: relative frequency (\%); RDo: relative dominance (\%); IV: importance value $(\%)$; CV: coverage value (\%).

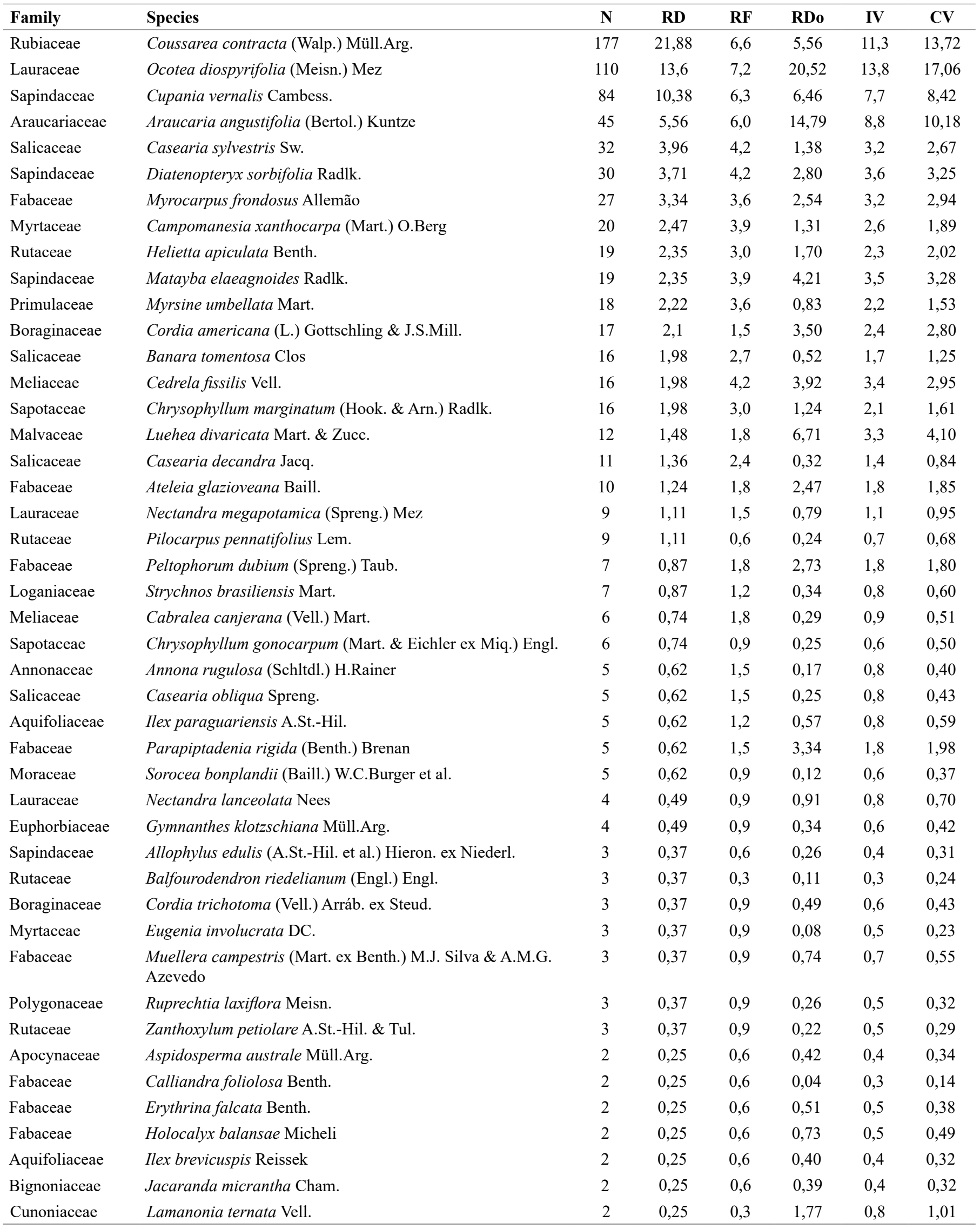


Continuation Table 2.

\begin{tabular}{|c|c|c|c|c|c|c|c|}
\hline Family & Species & $\mathbf{N}$ & RD & RF & RDo & IV & CV \\
\hline Lauraceae & Ocotea puberula (Rich.) Nees & 2 & 0,25 & 0,6 & 0,56 & 0,5 & 0,40 \\
\hline Euphorbiaceae & Sebastiania brasiliensis Spreng. & 2 & 0,25 & 0,3 & 0,11 & 0,2 & 0,18 \\
\hline Annonaceae & Annona neosalicifolia H.Rainer & 1 & 0,12 & 0,3 & 0,02 & 0,2 & 0,07 \\
\hline Fabaceae & Apuleia leiocarpa (Vogel) J.F.Macbr. & 1 & 0,12 & 0,3 & 0,22 & 0,2 & 0,17 \\
\hline Fabaceae & Inga virescens Benth. & 1 & 0,12 & 0,3 & 0,03 & 0,2 & 0,07 \\
\hline Fabaceae & Machaerium stipitatum Vogel & 1 & 0,12 & 0,3 & 0,05 & 0,2 & 0,08 \\
\hline Lauraceae & Ocotea pulchella (Nees \& Mart.) Mez & 1 & 0,12 & 0,3 & 0,03 & 0,2 & 0,08 \\
\hline Simaroubaceae & Picrasma crenata (Vell.) Engl. & 1 & 0,12 & 0,3 & 0,03 & 0,2 & 0,07 \\
\hline Apocynaceae & Tabernaemontana catharinensis A.DC. & 1 & 0,12 & 0,3 & 0,08 & 0,2 & 0,10 \\
\hline Rutaceae & Zanthoxylum kleinii (R.S.Cowan) P.G.Waterman & 1 & 0,12 & 0,3 & 0,02 & 0,2 & 0,07 \\
\hline
\end{tabular}
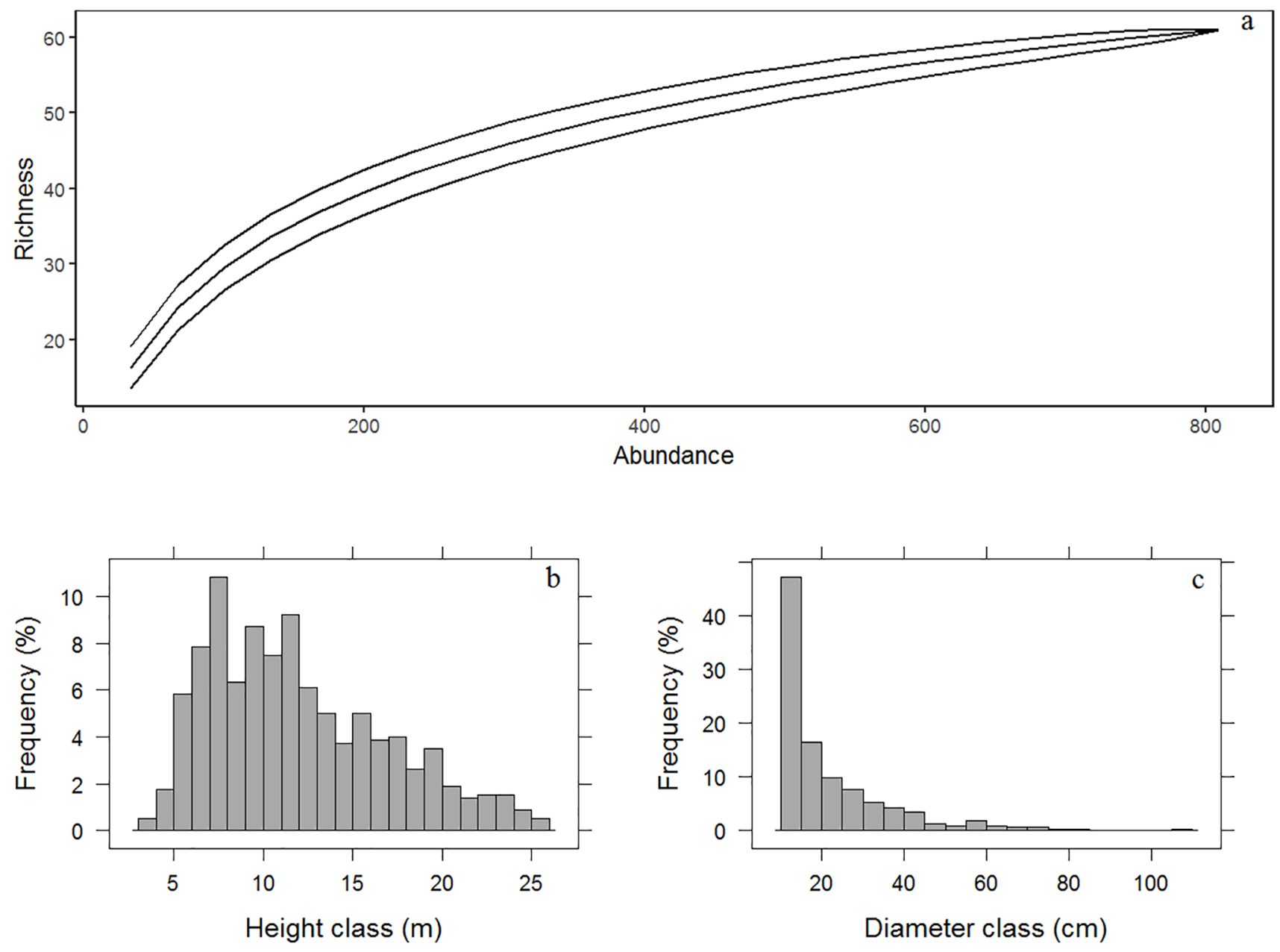

Figure 2. Tree community structure of Chapecó National Forest, west Santa Catarina, southern Brazil. a) Sample adequacy represented by a rarefaction curve standardizing a number of species and individuals. Upper and lower line estimates are also showed. b) Height distribution from three to 26 meters height. c) Diameter classes from $9.54 \mathrm{~cm}$ to $107 \mathrm{~cm}$, with intervals of five centimeters each class. The first class presents all individuals with $9.54 \mathrm{~cm}$ to $15 \mathrm{~cm}$ d.b.h. 


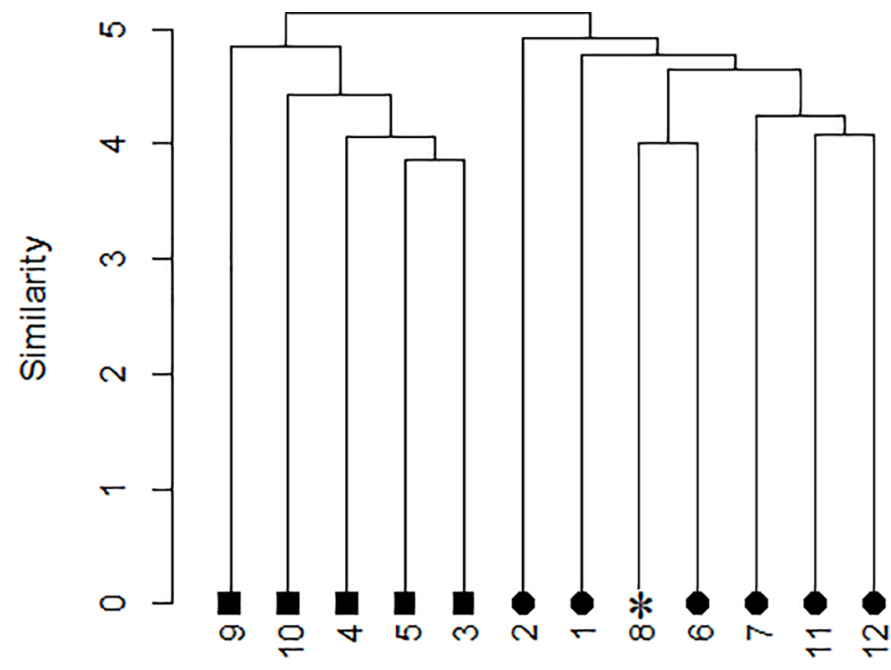

\section{Cluster (UPGMA)}

Figure 3. Cluster analysis, using the unweighted pair group method with arithmetic mean (UPGMA) and Jaccard similarity coefficient demonstrating the floristic similarities of 12 studies sampled at Araucaria and Seasonal forests, in southern Brazil. Cophenetic Correlation Coefficient $=0.9092$. See table 1 and fig 1 for site codes.

The species with higher importance values are common and important in other surveys in the Araucaria and Seasonal forests of Santa Catarina (Gasper, Uhlmann, et al. 2013, Gasper, Sevegnani, et al. 2013, Gasper et al. 2015, Vibrans et al. 2011, Schneider \& Rocha 2014, Vibrans et al. 2013a, 2012). Ocotea diospyrifolia, Cupania vernalis, Casearia sylvestris, Diatenopteryx sorbifolia and Myrocarpus frondosus are common at Seasonal forest (Fontana \& Sevegnani 2012) and $A$. angustifolia, Coussarea contracta e Cupania vernalis, are typical from components of early and intermediate successional stages in the Araucaria forest of Santa Catarina (Klauberg et al. 2010, Vibrans et al. 2011). According to Gasper et al. (2015), Cupania vernalis, Diatenopteryx sorbifolia and Myrocarpus frondosus characterize the transitional forests from the west of Santa Catarina.

We did not observe the asymptotic richness level in the rarefaction curve. It was found in other studies and was justified by the environmental heterogeneity or human influence in the landscape (Ruschel et al. 2007, Benvenuti-Ferreira \& Coelho 2009). Also, it is important to remember that forest communities are dynamic entities, where species are associated with some spatial and temporal variations (Schilling \& Batista 2008). In our study, this result is probably related to this dynamic and either the small number (24) and big size of each sampling unit $\left(500 \mathrm{~m}^{2}\right)$, whereas the usually recommended for these studies are sampling units that maximize the sampling area (e.g. more sampling units with a smaller size).

The inverted-J curve of diameter classes found in this study is common for different forest typologies and it indicates the forest regeneration and permanence of the species in forest structure (Balbinot et al. 2016). Most individuals sampled are small trees of the forest understory and it is also indicative of forest regeneration capacity (Cunha \& Silva Jr. 2012). On the other hand, individuals in the biggest size classes usually represent species with greater longevity (Chao et al. 2008) and their mortality contributes to de gap dynamics in forests (Yamamoto 2000).
Fabaceae frequently exhibits great species richness at Seasonal forests in southern Brazil (Jurinitz \& Jarenkow 2003, Benvenuti-Ferreira $\&$ Coelho 2009). It is related to the immigration corridor of the Uruguay and Paraná river basins, which connects the species of Fabaceae from the north to southern Brazil. However, further from the corridor towards the south, the number of species of this family decreases (Budke et al. 2005, Benvenuti-Ferreira \& Coelho 2009, Jurinitz \& Jarenkow 2003). On the other hand, Lauraceae species are usually described as highly abundant in the Araucaria forest, acting as indicator species associated to this forest typology (Gasper, Sevegnani, et al. 2013). Leyser et al. (2009) demonstrated high species richness of Fabaceae and Lauraceae in the transitional area between Araucaria and Seasonal forest, as found in this study, which may also indicate an association between these families in ecotonal areas. In general, Myrtaceae species are widely distributed in Atlantic forest s.l., but with lower abundance in the SF of Santa Catarina, leading to a rare occurrence specially driven by the climatic filters in the region (Fontana et al. 2014). These associations reflect complex species interactions which may also contribute powerfully to forest structuring and patterns of species distributions, leading to more studies and efforts in ecotonal areas.

\section{Floristic relationships between two forest typologies}

Despite the presence of $A$. angustifolia, the transitional forest of this study has great floristic similarity to the Seasonal forest. According to the cluster analysis, the vegetation type was the main grouping factor, followed by geographical proximity, as observed by other authors (Oliveira-Filho et al. 2001, Gonçalves \& Souza 2014, Estevan et al. 2016). The species composition of our study area must be also related to the altitude of the region, which is close to Uruguay river valley (around $600 \mathrm{~m}$ a.s.1.). In general, altitude is considered an important variable for the species distribution in the Atlantic forest s.l. (Eisenlohr et al. 2015), especially for Araucaria forest species, which occurrence is conditioned by higher altitudes, leading to higher local densities (Backes 2009, Higuchi et al. 2012, Viani et al. 2011). In our case, the lower altitude could be acting as an environmental filter (Higuchi et al. 2012), associated with the great amplitude and thermal seasonality and higher maximum temperature in the hottest month leading to the limitation of the species range of the Araucaria forest and with a pronounced presence of the Seasonal forest species (Gasper, Uhlmann, et al. 2013, Gasper et al. 2015).

Among the potential drivers associated to species occurrence and distribution, the biogeographic factor is another important driver related to actual species occurrence and communities diversity in southern Brazil (Rezende et al. 2016). It may be thus related to the species composition of Seasonal forests, which is also promoted by dispersal from Paraná river basin and the Misiones forests (Gasper et al. 2012) and leads to higher species diversity and great floristic similarity to rainforests (Eisenlohr \& Oliveira-Filho 2015; Rezende et al. 2016). In the other hand, the Araucaria forest has a low number of unique species (Eisenlohr \& Oliveira-Filho 2015) and presents physiognomic, floristic and structural differences throughout its distribution (Jarenkow and Budke 2009; Higuchi et al. 2012), leading to a particular forest structure and composition, different from other forest types (Eisenlohr \& Oliveira-Filho 2015). This forest occurs mainly in regions with higher altitude and has a gradual overlap of the species towards southwestern Brazil, making contact with the Seasonal forest species on Uruguay and Paraná river basins (Jarenkow and Budke 2009). 
Regard to the $A$. angustifolia dynamics along the time in this forest, there is a clear pattern of reduction of the population (Bordin 2018), which reinforces the Seasonal forest species turnover on the Araucaria forest species. Paleoecological analysis in the Araucaria forest areas at Rio Grande do Sul state revealed that population of $A$. angustifolia was much larger than today, where we can find typical semi-deciduous species occurring in these areas (Behling et al. 2016). It indicates that same pattern of turnover from Araucaria to Seasonal forest species composition is a trend found in other Atlantic Forest s.l. areas.

The subtropical forest presented here is well structured and highly diverse. Also, is an extremely important forest fragment for the local and regional biodiversity conservation, especially due to the presence of Seasonal forest species (Bergamin et al. 2017).

Concerning to forest characterization, despite the presence of Araucaria angustifolia, the species composition is closely related to the Seasonal forests, reinforcing the strong west-east pattern of species composition. Briefly, Seasonal forest is the floristic classification that should be considered in further analysis. This turnover of species along the regions strengthens the conservation necessity for protecting this pool of species and remaining forested areas, especially in this conservation unit.

\section{Acknowledgements}

We are grateful to ICMBio (License $\mathrm{n}^{\circ} 56024 / 2017$ ) for the logistical support during the sampling; to the fieldworkers Cristiano Ilha, Marciela Batistela and Francieli Delazeri and to Unochapecó for the logistical support and equipment. We also thank the two anonymous reviewers for the valuable suggestions. KMB has financial support from Coordenação de Aperfeiçoamento Pessoal de Nível Superior.

\section{Author Contributions}

Kauane Maiara Bordin: contributed in the concept and design of the study, data collection, data analysis, interpretation and to manuscript preparation, providing critical revision, and adding intellectual content.

Letícia Daiana Ferreira, Adriano Rosina, Marciana Malacarne, Patricia Zanotelli: contributed to data collection and intellectual content

Samuel Fernando Adami: data analysis, interpretation and to manuscript preparation and intellectual content.

Giovana Secretti Vendruscolo: contributed in the concept and design of the study, data collection, data analysis, interpretation and to manuscript preparation, providing critical revision, and adding intellectual content.

\section{Conflict of interest}

The authors declare that they have no conflict of interest related to the publication of this manuscript.

\section{References}

BACKES, A. 2009. Distribuição geográfica atual da Floresta com Araucária: condicionamentos climáticos. In Floresta com Araucária: Ecologia, Conservação e Desenvolvimento Sustentável (C. R. Fonseca, A. F. Souza, A. Leal-Zanchet, T. Dutra, A. Backes, \& G. Ganade, eds) Holos Editora, p. 328.
BALBINOT, R., LAMBRECHT, F.R., BREUNIG, F.M., TRAUTENMULLER, J.W., GALVÃO, L.S., DENARDI, L. \& VENDRUSCOLO, R. 2016. Análise fitossociológica de um fragmento de Floresta Estacional Decidual: Parque Estadual do Turvo, RS. Pesqui. Florest. Bras. - Brazilian J. For. Res. 36(86): 103-113.

BEHLING, H., VERISSIMO, N., BAUERMANN, S., BORDIGNON, S. \& EVALDT, A. 2016. Late holocene vegetation history and early evidence of Araucaria angustifolia in Caçapava do sul in the lowland region of Rio Grande do Sul State, southern Brazil. Brazilian Arch. Biol. Technol. 59(December):1-10.

BENVENUTI-FERREIRA, G. \& COELHO, G.C. 2009. Floristics and structure of the tree component in a Seasonal Forest remnant, Chiapetta, Rio Grande do Sul State, Brazil. Brazilian J. Biosci. 7(4):344-353.

BERGAMIN, R.S., BASTAZINI, V.A.G., VÉLEZ-MARTIN, E., DEBASTIANI, V., ZANINI, K.J., LOYOLA, R. \& MÜLLER, S.C. 2017. Linking beta diversity patterns to protected areas: lessons from the Brazilian Atlantic Rainforest. Biodivers. Conserv. 26(7):1557-1568.

BORDIN, K.M. (2018) Dinâmica da biomassa em uma floresta subtropical: efeito de componentes bióticos e abióticos. Dissertação. Universidade Federal do Rio Grande do Sul.

BUDKE, J.C., ATHAYDE, E.A., GIEHL, E.L.H., ZÁCHIA, R.A. \& EISINGER, S.M. 2005. Composição florística e estratégias de dispersão de espécies lenhosas em uma floresta ribeirinha, arroio Passo das Tropas, Santa Maria, RS, Brasil. Iheringia - Ser. Bot. 60(1):17-24.

CHAO, K.J., PHILLIPS, O.L., GLOOR, E., MONTEAGUDO, A., TORRESLEZAMA, A. \& MARTÍNEZ, R.V. 2008. Growth and wood density predict tree mortality in Amazon forests. J. Ecol. 96(2):281-292.

CORNWELL, W.K. \& ACKERLY, D.D. 2009. Community Assembly and Shifts in Plant Trait Distributions across an Environmental Gradient in Coastal California Published by: Ecological Society of America Community across an environmental in plant trait distributions assembly and shifts gradient and. Ecol. Monogr. 79(1):109-126.

CUNHA, M.D.C.L. \& SILVA JR., M.C. 2012. Estrutura diamétrica e hipsométrica na Floresta Estacional Semidecidual Montana do Pico do Jabre - PB. Rev. Bras. Ciencias Agrar. 7(2):292-300.

EISENLOHR, P. V. \& OLIVEIRA-FILHO, A.T. de. 2015. Revisiting Patterns of Tree Species Composition and their Driving Forces in the Atlantic Forests of Southeastern Brazil. Biotropica 47(6):689-701.

EISENLOHR, P. V., OLIVEIRA-FILHO, A.T. de \& PRADO, J. 2015. The Brazilian Atlantic Forest: new findings, challenges and prospects in a shrinking hotspot. Biodivers. Conserv. 24(9):2129-2133.

ESTEVAN, D.A., VIEIRA, A.O.S. \& GORENSTEIN, M.R. 2016. Estrutura E Relações Florísticas De Um Fragmento De Floresta Estacional Semidecidual, Londrina, Paraná, Brasil. Ciência Florest. 26(3):713.

FERREIRA, T. de S., MARCON, A.K., SALAMI, B., RECH, C.C.C., MENDES, A.R., CARVALHO, A.F., MISSIO, F. de F., PSCHEIDT, F., GUIDINI, A.L., DORNELLES, R. da S., SILVA, A.C. \& HIGUCHI, P. 2016. Composição florístico-estrutural ao longo de um gradiente de borda em fragmento de floresta ombrófila mista alto-montana em Santa Catarina. Cienc. Florest. 26(1):123-134.

FONTANA, C., GASPER, A.L. \& SEVEGNANI, L. 2014. Espécies raras e comuns de Myrtaceae da Floresta Estacional Decidual de Santa Catarina, Brasil. Rodriguesia 65(3):767-776.

FONTANA, C. \& SEVEGNANI, L. 2012. Quais são as espécies arbóreas comuns da Floresta Estacional Decidual em Santa Catarina? Rev. Estud. Ambient. 14(1esp):74-88.

GASPER, A.L. de, SEVEGNANI, L. \& VIBRANS, A. 2013. Inventário florístico florestal de Santa Catarina: espécies da Floresta Ombrófila Mista. Rodriguésia 64(2):201-210.

GASPER, A.L. De, UHLMANN, A., SEVEGNANI, L., LINGNER, D.V., RIGON-JÚNIOR, M.J., VERDI, M., STIVAL-SANTOS, A., DREVECK, S., SOBRAL, M., VIBRANS, A.C. \& DECIDUAL, E. 2013. Inventário Florístico Florestal de Santa Catarina: espécies da Floresta Estacional Decidual. Rodriguésia 64(3):427-443. 
GASPER, A.L. de, UHLMANN, A., VIBRANS, A.C. \& SEVEGNANI, L. 2015. Variação da estrutura da floresta estacional decidual no estado de Santa Catarina e sua relação com a altitude e clima. Ciência Florest. 77-89.

GASPER, A.L., SEVEGNANI, L., MEYER, L., SOBRAL, M., VERDI, M., STIVAL-SANTOS, A., DREVECK, S., KORTE, A. \& UHLMANN, A. 2012. Flora vascular da Floresta Estacional Decidual em Santa Catarina. In Inventário Florístico Florestal de Santa Catarina: espécies da Floresta Estacional Decidual Edifurb, p.111-122.

GONÇALVES, E.T. \& SOUZA, A.F. 2014. Floristic variation in ecotonal areas: Patterns, determinants and biogeographic origins of subtropical forests in South America. Austral Ecol. 39(1):122-134.

GRIS, D., TEMPONI, L. \& DAMASCENO JUNIOR, G. 2014. Structure and floristic diversity of remnant semideciduous forest under varying levels of disturbance. Acta Bot. Brasilica 28(4):569-576.

HIGUCHI, P., SILVA, A.C. da, FERREIRA, T.S., SOUZA, S.T. de, GOMES, J.P., SILVA, K.M. da \& SANTOS, K.F. do. 2012. Floristic composition and phytogeography of the tree component of Araucaria Forest fragments in southern Brazil. Brazilian J. Bot. 35(2):145-157.

HUBBELL, S.. 2001. The Unified Neutral Theory of Biodiversity and Biogeography. Monograps in population biology.

IBGE - INSTITUTO BRASILEIRO DE GEOGRAFIA E ESTATÍSTICA. 2012. Manual Técnico da Vegetação Brasileira. 2a edição ed. Instituto Brasileiro de Geografia e Estatística - IBGE, Rio de Janeiro.

ICMBio. 2013. Plano de Manejo da Floresta Nacional de Chapecó. ICMBio, Instituto Chico Mendes de Conservação da Biodiversidade, Florianópolis.

JARENKOW, J. A., BUDKE, J. 2009. Padrões florísticos e análise estrutural de remanescentes de Florestas com Araucária no Brasil. In Floresta com Araucária: Ecologia, Conservação e Desenvolvimento Sustentável (C. R. Fonseca, A. F. Souza, A. Leal-Zanchet, T. Dutra, A. Backes, \& G. Ganade, eds) Holos Editora, p.328.

JARENKOW, J.A. \& WAECHTER, J.L. 2001. Composição, estrutura e relações florísticas do componente arbóreo de uma floresta estacional no Rio Grande do Sul, Brasil. Rev. Bras. Botânica 24(3):263-272.

JOLY, C.A., METZGER, J.P., TABARELLI, M., JOLY, C.A., JOLY, C.A., METZGER, J.P. \& TABARELLI, M. 2014. Experiences from the Brazilian Atlantic Forest: ecological findings and conservation initiatives. New Phytol. 204(3):459-473.

JUNYAN, Z., KEWU, C., RUNGUO, Z. \& YI, D. 2014. Changes in floristic composition, community structure and species diversity across a tropical coniferous- broadleaved forest ecotone. Trop. Conserv. Sci. 7(1):126-144.

JURINITZ, C.F. \& JARENKOW, J.A. 2003. Estrutura do componente arbóreo de uma floresta estacional na Serra do Sudeste, Rio Grande do Sul, Brasil. Rev. Bras. Botânica 26(4):475-487.

KLAUBERG, C., PALUDO, G.F., BORTOLUZZI, R.L.C. \& MANTOVANI, A. 2010. Florística e estrutura de um fragmento de Floresta Ombrófila Mista no Planalto Catarinense. Biotemas 23(1):35-47.

KLEIN, R.M. 1960. O aspecto dinâmico do pinheiro brasileiro. Sellowia $1217-44$.

KLEIN, R.M. 1963. Observações e considerações sobre o Planalto nordeste Catarinense. Sellowia 1539-56.

KLEIN, R.M. 1978. Mapa fitogeográfico do estado de Santa Catarina. In Flora Ilustrada Catarinense. (R. Reitz, ed.) Herbário Barbosa Rodrigues, p.24.

KRAFT, N.J.B., ADLER, P.B., GODOY, O., JAMES, E.C., FULLER, S. \& LEVINE, J.M. 2015. Community assembly, coexistence and the environmental filtering metaphor. Funct. Ecol. 29(5):592-599.

LEGENDRE, P. \& LEGENDRE, L. 2012. Numerical Ecology. Elsevier.

LEYSER, G., VINISKI, M., DONIDA, A.L., ZANIN, E.M. \& BUDKE, J.C. 2009. Espectro de dispersão em um fragmento de transição entre Floresta Ombrófila Mista e Floresta Estacional na região do Alto Uruguai, Rio Grande do Sul, Brasil. Pesqui. Série Botânica 60355-366.

LIEBSCH, D., MARQUES, M.C.M. \& GOLDENBERG, R. 2008. How long does the Atlantic Rain Forest take to recover after a disturbance? Changes in species composition and ecological features during secondary succession. Biol. Conserv. 141(6):1717-1725.
LINDENMAIER, D. de S. \& BUDKE, J.C. 2006. Florística, Diversidade E Distribuição Espacial Das Espécies Arbóreas Em Uma Floresta Estacional Na Bacia Do Rio Jacuí, Sul Do Brasil. São Leopoldo 57193-216.

LINGNER, D.V.; OLIVEIRA, Y.M.M.D.; ROSOT, N.C. \& DLUGOSZ, F.L. 2007. Caracterização da estrutura e da dinâmica de um remanescente de floresta de araucária no Planalto Catarinense. Pesquisa Florestal Brasileira 55: 55-66.

LUCAS, E.M. \& FORTES, V.B. 2008. Frog diversity in the Floresta Nacional de Chapecó, Atlantic Forest of southern Brazil. Biota Neotrop. 8(3):0-0.

MAGURRAN, A.E. 2004. Measuring biological diversity. Oxford, Blackwell Science. 256p.

MORELLATO, L.P.C. \& HADDAD, C.F.B. 2000. Introduction: The Brazilian Atlantic Forest. Biotropica 32(4b):786-792.

MUELLER-DOMBOIS, D. \& ELLEMBERG, H. 1974. Aims and methods of vegetation ecology. New York: John Wiley and Sons. $547 \mathrm{p}$

MYERS, N., MITTERMEIER, R.A., MITTERMEIER, C.G., DA FONSECA, G.A.B. \& KENT, J. 2000. Biodiversity hotspots for conservation priorities. Nature 403(6772):853-858.

NIMER, E. (1989) Climatologia do Brasil. 2nd ed. IBGE, Departamento de Recursos Naturais e Estudos Ambientais, Rio de Janeiro.

OLIVEIRA-FILHO, A., CURI, N., VILELA, E.. A. \& CARVALHO, D.. A. 2001. Variation in Tree Community Composition and Structure With Changes in Soil Properties Within a Fragment of Semideciduous Forest in South-Eastern Brazil. Geographical 58(1):139-158.

OLIVEIRA-FILHO, A.T., BUDKE, J.C., JARENKOW, J.A., EISENLOHR, P. V., NEVES, D.R.M. 2014. Delving into the variations in tree species composition and richness across South American subtropical Atlantic and Pampean forests. J. Plant Ecol. 8(3):242-260.

OLIVEIRA-FILHO, A.T. \& FONTES, M.A.L. 2000. Patterns of Floristic Differentiation among Atlantic Forests in Southeastern Brazil and the Influence of Climate. Biotropica 32(2):793-810.

OVERBECK, G.E., MÜLLER, S.C., FIDELIS, A., PFADENHAUER, J., PILLAR, V.D., BLANCO, C.C., BOLDRINI, I.I., BOTH, R. \& FORNECK, E.D. 2007. Brazil's neglected biome: The South Brazilian Campos. Perspect. Plant Ecol. Evol. Syst. 9(2):101-116.

R CORE TEAM. 2016. R: A language and environment for statistical computing. R Foundation for Statistical Computing. https://www.r-project.org/.

RAMBO, B. 1951. O Elemento Andino no Pinhal Riograndense. An. Botânicos do Herbário Barbosa Rodrigues 2(2):7-39.

RAMBO, B. 1953. História da Flora do Planalto Riograndense. An. Botânicos do Herbário Barbosa Rodrigues 5185-232.

REITZ, R., KLEIN, R.M. \& REIS, A. 1978. Projeto Madeira de Santa Catarina. Sellowia 2811-320.

REZENDE. V.L., BUENO, M.L., OLIVEIRA-FILHO, A,T. (2016) Patterns of tree composition in the southern cone of South America and its relevance to the biogeographic regionalization. Plant Ecology 217:97-110

RISSER, P.G. 1995. The status of the science examining ecotones. Bioscience 45(5):318-325.

RONDON-NETO, R.M., WATZLAWICK, L.F., CALDEIRA, M.V.W. \& SCHOENINGER, E.R. 2002. Análise florística e estrutural de um fragmento de Floresta Ombrófila Mista Montana, situado em Criúva, RS - Brasil. Ciência Florest. 12(1):29-37.

RUSCHEL, A.R., NODARI, R.O. \& MOERSCHBACHER, B.M. 2007. Woody plant species richness in the Turvo State park, a large remnant of deciduous Atlantic forest, Brazil. Biodivers. Conserv. 16(6):1699-1714.

SANTOS, C.S. dos, CHIOSSI, R.Y., GASPARIN, AVILA, A.L. de \& GASPARIN, E. 2012. Levantamento florístico e fitossociológico de um fragmento florestal no município de Faxinal dos Guedes, SC. Unoesc e Ciência - ACET 3(1):7-22.

SCHILLING, A.C. \& BATISTA, J.L.F. 2008. Curva de acumulação de espécies e suficiência amostral em florestas tropicais. Rev. Bras. Botânica 31(1):179-187. 
SCHNEIDER, G. \& ROCHA, F.S. 2014. Levantamento florístico e fitossociológico do componente arbóreo de um fragmento de Floresta Estacional Decidual em São Miguel do Oeste, Santa Catarina. Biotemas 27(2):43-55.

SILVA, A.C. da, HIGUCHI, P., AGUIAR, M.D. de, NEGRINI, M., NETO, J.F. \& HESS, A.F. 2012. Relações florísticas e fitossociologia de uma floresta ombrófila mista montana secundária em lages, Santa Catarina. Ciência Florestalncia Florest. 22(1):193-206.

SPICHIGER, R., CALENGE, C. \& BISE, B. 2004. Geographical zonation in the Neotropics of tree species characteristic of the Paraguay-Paraná Basin. J. Biogeogr. 31(9):1489-1501.

THE ANGIOSPERM PHYLOGENY GROUP. 2016. An update of the Angiosperm Phylogeny Group Classification for the orders and families of floweringplants: APG IV. Bot. J. Linn. Soc. 1811-20.

VIANI, R.A.G., COSTA, J.C., ROZZA, A. de F., BUFO, L.V.B., FERREIRA, M.A.P. \& OLIVEIRA, A.C.P. de. 2011. Caracterização florística e estrutural de remanescentes florestais de Quedas do Iguaçu, Sudoeste do Paraná. Biota Neotrop. 11(1):115-128.

VIBRANS, A.C., SEVEGNANI, L., GASPER, A.L. de \& LINGNER, D. V. 2012. Inventário Florístico Florestal de Santa Catarina, vol II: Floresta Estacional Decidual. Edifurb.

VIBRANS, A.C., SEVEGNANI, L., GASPER, A.L. de \& LINGNER, D.V. 2013a. Inventário Florístico Florestal de Santa Catarina, vol IV: Floresta Ombrófila Densa. Edifurb.
VIBRANS, A.C., SEVEGNANI, L., GASPER, A.L. \& LINGNER, D.V. 2013b. Inventário Florístico Florestal de Santa Catarina, vol. III: Floresta Ombrófila Mista. Edifurb.

VIBRANS, A.C., SEVEGNANI, L., LINGNER, D.V., GASPER, A.L. de \& SABBAGH, S. 2010. Inventário florístico florestal de Santa Catarina (IFFSC): aspectos metodológicos e operacionais. Pesqui. Florest. Bras. 30(64):291-302.

VIBRANS, A.C., SEVEGNANI, L., UHLMANN, A., SCHORN, L.A., SOBRAL, M.G., GASPER, A.L., LINGNER, D. V., BROGNI, E., KLEMZ, G., GODOY, M.B. \& VERDI, M. 2011. Structure of mixed ombrophyllous forests with Araucaria angustifolia (Araucariaceae) under external stress in Southern Brazil. Rev. Biol. Trop. 59(3):1371-1387.

WAECHTER, J.L. 2009. Epífitos vasculares da Floresta com Araucária do sul do Brasil. In Floresta com Araucária: Ecologia, Conservação e Desenvolvimento Sustentável (C. R. Fonseca, A. F. Souza, A. Leal-Zanchet, T. Dutra, A. Backes, \& G. Ganade, eds) Holos Editora, p.328.

WARRING, B., CARDOSO, F.C.G., MARQUES, M.C.M. \& VARASSIN, I.G. 2016. Functional diversity of reproductive traits increases across succession in the Atlantic forest. Rodriguesia 67(2):321-333.

WRIGHT, S.J. 2007. Plant Diversity in Tropical Forests. In Functional plant ecology (F. I. Pugnaire \& F. Valladares, eds) Taylor \& Francis Group, p.748.

XU, J., CHEN, Y., ZHANG, L., CHAI, Y., WANG, M., GUO, Y., LI, T. \& YUE, M. 2017. Using phylogeny and functional traits for assessing community assembly along environmental gradients: A deterministic process driven by elevation. Ecol. Evol. 7(14):5056-5069.

YAMAMOTO, S.I. 2000. Forest gap dynamics and tree regeneration. J. For. Res. 5(4):223-229. 